- External reviewers knew that the project couldn't be built for $\$ 1.2$ billion, but declined to say so in public. According to Grunder, who served on a National Academy of Sciences panel that reviewed the NIF proposal in 1997, the panel believed that the project would cost $\$ 1.7$ billion to complete, but didn't put the figure in its published report. - In an effort to control costs, the NIF's 192 lasers are packed tightly together. Previous laser designs, such as Livermore's Nova facility, have been spread out on the ground, allowing technicians easy access during assembly. Clean assembly of NIF's lasers

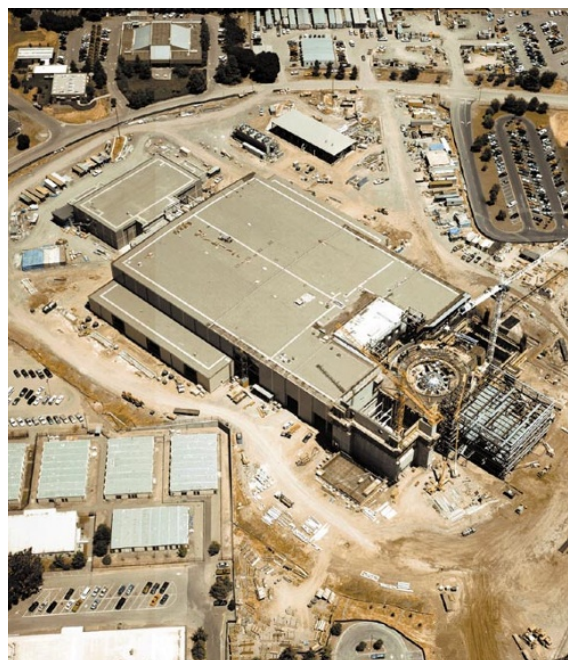

Costly: but NIF construction is proceeding steadily. will therefore be very difficult, although independent assessors say it can be done. "We did it so that the NIF could go in a realistically sized building," says Tarter. "We didn't appreciate the fact that if you packed the lasers closely together, lab technicians couldn't go in" and work on them during assembly.

- Research efforts, such as the Beamlet laser and a laser amplifier called Amplab, which were to have run in parallel with NIF construction and to answer questions critical to its success, were discarded early because of budgetary constraints. Tarter says Beamlet - a full-sized prototype of a NIF laser should have been kept running as a test bed for NIF technologies, instead of being shut down once it was established that it worked. - Other research efforts required to complete the project successfully, including investigation of the target 'hohlraums' for the facility and several issues related to the durability of its optical components, are short of resources. "The programme is in deep trouble in terms of the money it needs in very many areas," says one well-informed administration official in Washington.

On the plus side, the optical components identified by SEAB as falling furthest short of the necessary technical specification will be installed near the target chamber, and won't have to be slotted in until late in the construction schedule, giving researchers more time to improve their specification.

As part of a nuclear weapons programme unaccustomed to public scrutiny during the

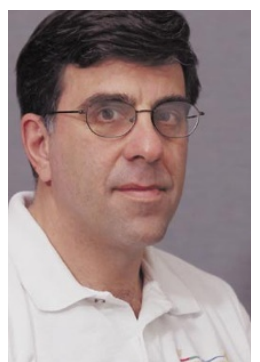

Cold War, the NIF received little outside supervision - or even supervision by Tarter —until last summer, by which time the project was in deep trouble. Government officials and scientists from outside the weapons labs Moses: upbeat. believe the NIF lacked the accountability now expected of publicly funded projects. As Grunder puts it: "Times had changed, but the people [in the weapons programme] hadn't".

A potential candidate for associate director after the reorganization is Moses. He currently reports to George Miller, Livermore's associate director for national security, who took on supervision of the NIF when the director of the project, Michael Campbell, resigned last September.

Strolling along the smooth concrete floor of the facility, which he describes as "the largest optical table in the world", Moses expresses confidence that a new contractor will solve the assembly problem. "We'll be working with people who built pharmaceutical and semiconductor plants," he says.

Moses, an electrical engineer with a background in project management, is strongly upbeat about the NIF construction, but won't speculate on how much it will eventually cost. "We're working through it as accurately as we can," he says. Colin Macilwain

\title{
Japan may allow human embryo stem-cell research
}

\section{Tokyo}

Research on human embryonic stem cells has come a step closer to being legalized in Japan, as the country's science policymakers prepare a proposal to the government endorsing such research.

A subcommittee of the Council for Science and Technology (CST), Japan's principal science policy-making body, is expected to submit its proposal to the CST by the end of the month. The proposal should receive approval by the end of March, then be submitted to the government.

The Science and Technology Agency, which manages the CST, will issue guidelines on cloning research and human genetic engineering at the same time.

The use of embryo cells for research is expected to be allowed subject to several conditions. First, that only cells from fertilized eggs less than 14 days old are used. Second, that no money is paid to donors for cells. Third, that research is limited to cells that were not used in fertility treatment.

Under a two-tiered approval system, an internal review board of the institution where the research is be carried out must endorse the research group's plan before sending it to the government for approval.

A major ethical split between obstetricians and prospective stem-cell researchers on the committee was resolved when it was decided that information about embryo donors would not accompany donated cells. Debates continue on the commercialization and patenting of research results.

The issue has stirred up little public interest, especially compared with last year's intense debates over organ transplants from brain-dead donors. But some researchers have voiced concern over the prospect of starting research before adequate regulatory laws or organizations are in place. One member of the stem-cell subcommittee argues that the CST is too weak. He wants to see an information protection law set up, with an authoritative body to oversee genetic and embryo research.

In the absence of these, he says, "research ethics in human embryology and genetics might be handed down to individual researchers or institutes, in which case unethical research protocols might be approved. As a consequence, public trust could be lost." This would undermine future research initiatives.

A Ministry of Health and Welfare working group will issue its own guidelines on the use of human genetic information by March (see Nature 402, 8; 1999), and the Ministry of Education, Sports and Culture (Monbusho) plans to set up an ethics review committee on human genome research within its managerial board in April.

Lack of a clear central policy, coupled with separate ministerial attempts to assert their own policy-making authority, has long characterized Japanese government activities. Resultant uncertainty in the private sector could severely hamper Japan's plans to lure venture businesses into biotechnology and create 1,000 start-up companies by 2010 (see Nature 397, 554; 1999).

"Unlike in the United States, Japanese businesses are not eager to take the initiative when legal and regulatory matters remain unsettled," one source warns. David Cyrano 